\title{
CONSUMER LEGAL PROTECTION AGAINST HOUSING DEVELOPERS: AN EXAMINATION OF SALE AND PURCHASE OF FLATS BEFORE COMMENCEMENT OF CONSTRUCTION PROCESS
}

\author{
Situmorang Palmer*, PhD candidate \\ Ahmad Rusniah, Noor Fauziah Bt. Mhd, Lecturers \\ College of Law, Government and International Studies, University Utara Malaysia, Malaysia
}

\author{
Nursadi Harsanto, Lecturer \\ University of Indonesia, Indonesia \\ *E-mail: palmer@palmersitumorang.com
}

\begin{abstract}
This paper aims to examine the importance of the law on consumer protection in Indonesia in the case of buying flats/apartments from developers who sell the properties before they develop them. There is a phenomenon where flat developers can market and sell units of flats/apartments to public even though the construction of flats has not been implemented and many legal requirements in terms of administrative, technical and ecological have not been fulfilled. This paper found that many developers sell units of flats/apartments when they have not fulfilled all the requirements including legal aspect from the government. Findings also show that although developers and consumers have a binding agreement in selling and buying flats/apartments, in this case, consumers are often in a weak position and incur losses compared to developers. This paper also highlights that there is still the absence of sanctions for developers who violate the regulation, although the law on consumer protection is enforced through regulating on the marketing of the units of flats/apartments. It is therefore, suggested that developers have to comply with the guideline of selling and buying of the units of flats/apartments based on the Decree of the Indonesian Minister of Public Housing. Thus, for developers who sell the units of flats/apartments improperly may be subject to criminal or imprisonment penalties. For instance, imprisonment or penalties result from making a binding agreement on selling and buying which have not fulfilled various requirements from the government. It is therefore asserted that the government and developers need to socialize the obligations of developers to consumer base Government Regulation Number 88 (2014), on the units of flat/apartment and on consumer rights. On the other hand, consumers should pay attention to legal aspect in buying a unit of flat/apartment. Thus, in terms of law, this paper suggests the need for revision of Law Number 20 (2011) and Law Number 1 (2011) to establish a regulation on sanctions for developers who sell units of flat/apartment in violation of all requirements.
\end{abstract}

\section{KEY WORDS}

Consumer, legal protection, developer, consumer, flat, apartment, regulations.

A settlement or housing is a primary need for human beings. However, settlement and housing cannot only be seen as a necessity of life, but also as the process of creating a good living conditions with an identity in society ${ }^{1}$. In the case of Indonesia, the country still provides a very limited portion of regulating in its constitution for giving a decent living and prosperity which are imperatively regulated in Article $28 \mathrm{H}$, paragraph 1 , of Indonesian Constitution of

\footnotetext{
${ }^{1}$ Adrian Sutedi in a book "Hukum Rumah Susun \& Apartemen/ Law of Flats and Apartment", published by Sinar Grafika in 2010, pp 162.

Lynne C. Manzo, "On uncertain ground: being at home in the

context of public housing redevelopment", on the journal of International Journal of Housing Policy, 14:4, 389-410, in 2014, argues that "home is a site where people feel most in control of their lives; and home is a secure base around which identities are constructed and she investigates how people's attachments to home-places have significant social, psychological and emotive consequences, as well as political and economic consequences".
} 
1945. The constitution states that everyone has the right to have a prosperous living, materially and immaterially, to live and to receive a good and healthy living environment. In relation to the rights, the country has responsibility to ensure the fulfillment of the right to have a decent and affordable home/resident ${ }^{2}$.

To meet the needs of housing/residence, the development of flats ${ }^{3}$ is an alternative solution to providing housing and settlement, especially in urban areas where population in the areas continues to increase ${ }^{4}$. The reason is that the development of flats can reduce the use of land, create more open spaces and be used as a way to rejuvenate the city from slum areas $^{5}$.

The essential problem of providing housing/settlement is about the provision of area or land as the center of its operational activities. In reality, the provision of land based on its availability is increasingly limited, both in terms of quality and quantity. At the same time, land utilization or construction activities for various purposes are increasing. Recognizing this reality, the Indonesian Government develops the concept of residential development that a location or plots of land can be shared together in Multi-storey flats where each unit can be owned separately ${ }^{6}$. Thus, the idea of flats can give benefits of: 1) supporting concept of layout related to improvement of city development in vertical direction and to upgrade scum areas; 2) improving maximization of land resource of the city; 3) supporting development of settlement in high densely populated area $^{7}$.

In fact, Indonesia has a legal instrument in the form of laws that specifically regulate flats, namely the Law of the Republic of Indonesia Number 20 Year 2011 on flats (Undangundang Rumah Susun/UURS). Based on the law, flats are defined as multilevel buildings, constructed in an environment divided into functionally structured sections; each unit can be owned and used separately, especially for shelters which are equipped with shared parts,

\footnotetext{
${ }^{2}$ Raquel Rolnik, on the journal "Place, Inhabitance and Citizenship: the right to housing and the right to the city in the contemporary urban world", in the International Journal of Housing Policy, 14:3, 293-300, in 2014, saying that there is a clear connection of how 'location' is an essential element of the right to adequate housing, as it is the most straightforward link between housing, inhabitance and citizenship.

${ }^{3}$ Concerning the term of apartment, Adrian Sutedi in ibid. P. 275, considering that flats can be called apartments. The term of apartment in Dutch is called appartement or apartment. Apartment in English is called apartment, while in French it is called appartement. When the terms are translated into Indonesian, it can be interpreted as part of residence/living in the form of rooms, chambers, or in Dutch is called kamer or vertrek. In addition, there are other terms in the Dutch language that flat or flatgehoouw can be translated as a house/building that is usually occupied by people as a independent residence.

${ }^{4}$ Arie S. Hutagalung, on the book of "Condominiums and Their Issues, Revised Edition", published by Legal Firm, University of Indonesia, Jakarta, in 2007, pp. 3. The Government considers the necessary to develop the concept of housing development that can be shared in a multi-storey building, where the units can be separately owned either horizontally or vertically. Such development is in accordance with the needs of today's society, especially the urban community. Suhadi, on the book of "Legal and Social Aspects of Flats", published by Badan Penerbit Fakultas Hukum Universitas Negeri Semarang, in 2017, pp. 27 and pp. 34 said that the development of flats has now become a trend in both developed and developing countries in an effort to meet the housing needs for urban residents. The development of flats is implemented in order to increase the efficiency and effectiveness of the use of urban land which is increasingly limited, on the other hand, the urban population is growing rapidly. In addition, the development of flats occurs as an effort of the government in creating residential which is feasible for its inhabitants. Public Communication Center at Ministry of Public Works and People's Housing of the Republic of Indonesia, "Backlog of Housing Achieve 5.8 Million Units," at https://www.pu.go.id/berita/view, accessed on 1st March, 2018. Head of Research and Development Agency (Balitbang) the department of Public Works (PU) Hendrianto Notosoegondo revealed that the needs of homes which have not served (backlog) currently reached at 5.8 million units. Although national population growth tends to decline from around 1.98 percent annually in 1980 - 1990 to 1.4 percent annually in 1990 - 2000, but the growth of urban population in 1990 - 2000 was still quite high at 3.5 percent per year.

${ }^{5}$ Arie S. Hutagalung, on the book of "Tebaran Pemikiran Seputar Masalah Hukum Tanah/Spreading Thoughts on Land Law Problems", published by Indonesian Institute for Legal Empowerment, Jakarta in 2005, pp. 281. The development of flats is significantly considered an alternative solution to resolve the problem of housing and settlement needs in urban areas whose population continues to increase. Since the development of flats/apartments can reduce the use of land, this situation makes the urban open spaces more spacious, and the development of flats can therefore be used as a way to city rejuvenation from slum areas. The construction of such housing is in accordance with the need of today's society, especially the urban community by using a condominium system, which is a system of ownership of buildings in which there is a unit which can be used separately and individually owned. Although there is also joint ownership of shared parts, shared objects and land. While Eddy Marek Leks (Chairman of the Working Group), in "Analysis and Evaluation of Legislation Regulations on Public Housing," National Center for Legal Counsel of the Ministry of Justice and Human Rights, 2013, pp. 64. Life in big cities in Indonesia is increasingly uncomfortable due to the increase of the density of the population, lack of green areas and open spaces. Therefore, environmental problems in residential areas generally arise as a result of high levels of urbanization and industrialization and the impact of less controlled use of resources and technologies.

${ }^{6}$ Arie S. Hutagalung in his book "Kondominium dan Permasalahannya/Condominium and its Problem", Op.cit., pp. 99.

${ }^{7}$ Government Regulation of the Republic of Indonesia Number 4 Year 1998 concerning Flat.
} 
common objects, and common area/land ${ }^{8}$. The law introduces a new ownership entity as a property right, that is, the property rights of an apartment unit (Hak Milik atas Satuan Rumah Susun/HMSRS), consisting of individual rights over units of flat/apartment and of collective rights to land, objects and common parts which constitute an inseparable unit with others ${ }^{9}$.

Actors in the development of flats, hereinafter used are developers have promoted, marketed or sold flat/apartment units, although the building construction has not been completed yet. Indeed, marketing activities by developers prior to the development of flats can be practiced under the provisions of Article 42 paragraph (1) of the law on flat/UURS. However, to be able to sell before finishing the development of flats, developers must meet several important requirements such as legal certainty of space designation and legal certainty of land rights. Besides regulated in the UURS, selling flats prior to the development of the flats are also discussed in the provisions of Article 42 (1) of Law Number 1 Year 2011 on Housing and Settlement Area of Law Number 1 Year 2011, stating that flats which are still in the process of development/construction can be marketed through a system of preliminary sale and purchase agreement in accordance with the provisions of legislation and law.

However, rules and regulations related to the marketing of flats are still very limited in Indonesia, whereas basic information about legal aspect of land and building hold by developers becomes very important issues for consumers. In reality, the promotion and marketing of apartment/flat units are carried out by developers are not meeting with all requirements to sell the units to consumers prior to development ${ }^{10}$, for instance, the developers have not met legal requirement of the local government. As a result, the construction project or development of flats/apartment is requested to be temporarily or permanently terminated ${ }^{11}$. This problem certainly would potentially harm consumers who make purchases in advance of units of flats/apartments.

\footnotetext{
${ }^{8}$ Indonesian law uses the term "flats". There is another term which is also often used, namely "condominium," as Adrian Sutedi, Op.cit., pp. 139 says that a condo is a form of housing function in which a particular part of real estate, generally privately owned apartments, while the use and access to facilities such as aisles, heating systems, elevators are under law associated with private ownership and it is controlled by the association of owners. This term is often used to refer to the unit itself replacing of the word "apartment". Currently, there are many apartments/condominiums are sold to consumers using the words selling apartments or selling condos. Condominium is a legal term used in the United States and in parts of Canada. In Australia and the province of British Columbia in Canada is called a strata title. In Quebec, the syndicate of co-ownership is used. In England and Wales, it is the same as commonhold, a form of ownership introduced in 2004.

${ }^{9}$ Arie S. Hutagalung, "Kondominium dan Permasalahannya/Condominium and its Problems", Op.cit., pp. 9. A law on flat called Undang-Undang Rumah Susun (UURS) revokes and declares no applicable to previous Law on Flats, namely Law Number 16 of 1985 on Flats (Statute Book of Year 1985 Number 75, Supplement to Statute Book of the Republic of Indonesia Number 3318). However, UURS declares that all laws and regulations which are the implementing regulations of Law Number 16 Year 1985, regarding Flats shall remain valid as long as they are not contradictory or have not been replaced by the new implementing regulations under UURS.

${ }^{10}$ Erwin Kallo, in "Panduan Hukum untuk Pemilik/Penghuni Rumah Susun (Kondominium, Apartemen dan Rusunami), the Legal Guide for Owners /Residents of Flats (Condominiums, Apartments and Rusunami)", published by Minerva Athena Pressindo, Jakarta, in 2009, pp. 23-24 argues that recently many marketers or property agents are offering residential unit selling with a pre-selling pattern or selling strategy by offering residential units of flats through various property exhibitions, either individually or jointly to consumers. While the physical buildings offered by the developers are usually still in the form of a picture of building and on the brochure information.

11 Hendra Kusuma, on Detik Finance, "Deddy Mizwar asked Meikarta Project to be stopped," https://finance.detik.com, accessed on 1 March, 2018. Lippo Group as a development agent is requested by the Vice Governor of West Java to temporarily suspend the development project of Kota Baru Meikarta, in Cikarang, Bekasi. The reason is that, in the Regional Regulation (Perda) Number 12 of 2014 on Management of Development and Development of Metropolitan and Growth Center, development of area in regency / city that become part of metropolitan must get recommendation from West Java Provincial Government. The development area of Kota Baru Meikarta includes the metropolitan area that will be developed in West Java Provincial Government so that it requires the recommendation of West Java Provincial Government. As a result of not having the recommendation, the Meikarta area development project was asked to be temporarily stopped. Zulfi Suhendra on Detik Finance with the title "This reason Deddy Mizwar only gives Meikarta 84 Ha Recommendation", at https://finance.detik.com, which was accessed in February 16, 2018. The Provincial Government of West Java has recommended only 84.6 hectares for land development project of Kota Baru Meikarta. The West Java Provincial Government has recommended to the Bekasi Regent for the use of 84.6 hectares of land in Cikarang, West Java for the Meikarta development project. The recommendation has been given to the Bekasi Regent because the Regent is applying but the extent is only 84.6 hectares, not 500 hectares. Luthvi Febryka Nola, "Legal issues in pre-project selling apartment practice,", in brief legal magazine, research center of the Indonesian parliament's expertise agency ISSN Vol. IX, No. 18/II/Puslit/September/2017, www.puslit.dpr.go.id., accessed in March 27, 2018. Other examples related to the marketing of flats prior to development are Kalibata City Apartments, where the developer has conducted marketing apartment for 25 floors at the time the permit has not been fully obtained. For safety reasons, the Jakarta Provincial Government only issued permits for 20 floors. Finally, developers could not fulfill the promise to do development for 21 to 25 floors so that there were a dispute between developers and consumers who have already booked the units. Another example is in 2016, when Bintaro Icon Apartment was also sealed by the South Tangerang City Police Force because it did not have a permit to construct/build (IMB) when the marketing of the units had been conducted since July 2013.
} 
Based on potential various problems which could occur in the marketing of flats before the development/construction of the flats, it is clear that there is the weakness of the regulation on the marketing or selling the units of flats or apartments by developers, Law Number 20 Year 2011 and Law on Governing of Housing and Settlement Areas, Law Number 1 Year 2011. On this basis, this paper examines the consumer protection law towards developers who conduct marketing before the development/construction of flats. Thus, this paper is intended to examine how consumer legal protection works for the actions of developers who conduct marketing and selling flats/apartments before the development of the units are undertaken and before developers meet with all the requirements including legal aspect such as on legal administration, technique and ecology.

\section{RESULTS AND DISCUSSION}

Buyers as Consumers Unit Flats. Flats based on the Indonesian law on flat/UURS are multilevel buildings constructed in an environment divided into functionally structured sections, either horizontally or vertically and are units that each can be owned and used separately, especially for shelter which are equipped with shared parts, common objects, and common ground ${ }^{12}$. Flats consist of apartment units, which are apartment units whose main purpose is used separately with main function as residential and have means of connecting to public road ${ }^{13}$. Buyers or consumers make purchases of apartment units as products marketed by developers or business entities engaged in marketing ${ }^{14}$.

Referring to the Article 1 of Law Number 8 Year 1999 on Consumer Protection (UUPK), a consumer is defined as each user of apartment unit built by the developer. As consumers, buyers of apartment units have several rights. Apartment buyers are entitled to the convenience, security and safety of housing units. The buyer is also entitled to the right, clear and honest information and then to vote and get the apartment units in accordance with the exchange rates, conditions and promised warranties ${ }^{15}$. In addition, buyers of apartment units

As a result of the sealing, consumers are restless and postponed the payment of installments until the licensing process was completed.

${ }_{12}$ The Indonesian law uses the term "flats". Moreover, there is another term that is often used, namely "condominium," as Adrian Sutedi, Op.cit., pp. 139. A condominium is a form of right to use housing in which a particular part of real estate, generally privately owned, while the use and access to facilities such as aisles, heating systems, elevators are under law associated with private ownership and the condominium is controlled by the owner associations, depicting the ownership of all parts. This term is often used to refer to the unit itself in place of the word "apartment". There are a number of the developments of flat/apartment which lead to massive approach to consumers, through selling flats/ apartments/condos. Condominium is a legal term used in the United States and parts of Canada. In Australia and the province of British Columbia in Canada is called a Strata Title. In Quebec, the syndicate of co-ownership is used. In England and Wales the same as Common-hold, a form of ownership introduced in 2004 and unusual in some places. Compare to Arie S Hutagalung in the Condo and the Problem, Op.cit., pp. 3. Condominium comes from a Latin word consisting of the word "Con" which means together, and the word "Dominium" which means ownership. In subsequent developments, the condominium has the meaning of a building property consisting of parts which each of them constitutes a union that can be used or occupied separately, and individually owned.

${ }^{13}$ Arie Hutagalung, "Tebaran Pemikiran Seputar Masalah Hukum Tanah Spreading Thoughts on Land Law Problems", Op.cit., pp. 77. Individual apartment units are owned by the owners themselves, whereas the collective rights shall be used and managed jointly as they concern to the common interests. Association of Owners and Residents of Flats (P3SRS) by legislation is given the status as a legal entity in which the organizational structure, rights and obligations are regulated in its articles of association and bylaws. Thus, Association of Owners and Residents of Flats/P3SRS can act on behalf of owners and occupants of the flats/apartments and with its authority can bring rules of order and peace to the environment of flats/apartments.

${ }^{14}$ Black's law dictionary of free online legal dictionary 2nd addition defines a product as follows: "1) a product that is in its finished stage is usually at the end of a production cycle. It is usually what a user needs or wants. 2) In terms of law where a product should be a good distributed commercially by having tangible personal property, the result of a fabrication or production process, and passed through the distribution channel before the consumption of the good. 3) Marketing for a good or service should provide exactly what the buyer wants or need and the profit margin must be justifiable for it to be in production. 4) Finished product, usually at the end of the production cycle, is usually what is needed or desired by the user. Sudjana and Elisatris Gultom, on the book of "Trade Secret in the Perspective of Consumer Protection", published by Keni Media, Bandung, in 2016, pp. 27. Kotler defines a product is anything that can be offered to market in order to get attention, to be bought, used, or consumed and it can satisfy the wants or needs of people. Tan Kamelo on the book of "Practice Protection for Consumers in Indonesia as a Result of Foreign Products in the National Market", paper addressed education and training of trade law management, by Ministry of Industry and Commerce RI Regional Office of Ministry of Industry and Trade of North Sumater Province. The institution defines production is any activity aimed to produce goods and services. In a broader sense, production is any action aimed to create or add value to a good.

${ }^{15}$ Eddy M. Leks, on the book of "Practical Property Law Guide-Understanding the Problems of Land Law, Housing, and Development", published PT Gramedia Pustaka Utama, Jakarta, in 2016, pp. 118-119. The law of flat/UURS provides convenience to developers on public housing in the form of incentives such as facilities in land procurement, facilities in land 
are entitled to compensation, compensation and/or reimbursement, if the apartment units received by buyers are not in accordance with the agreement or not as the units should be.

Requirements for Housing Development. Flats are built by developers as business actors. The developer may be either an individual or a business entity, whether in the form of a legal entity or not. The development of flats undertaken by developers must follow several stages in accordance with the provisions of legislation, namely, technical planning, implementation, and technical supervision. In addition, in line with those stages, some other requirements in the development of flats should also meet administrative, technical and ecological requirements.

Unlike the development of regular housing, the development of flats requires stricter on technical and administrative requirements because flats have specific form of building and context $^{16}$. The administrative requirements which must be fulfilled is in the license to develop flats/apartments including the status of land rights and building permits/ plan for constructing permit (Ijin Mendirikan Bangunan/IMB). In this regard, developers of flats and environment must follow the plan for area/land function and utilization. License is obtained from Regents or Mayors, but especially for Jakarta Province, the plan for function and utilization must be obtained from the Governor of Jakarta. The application for the permit to build the flats/apartments is submitted by the developer with enclosing requirements of the land certificate, the certificate of district/municipality plan; the picture of the site plan, the picture of architectural and design plan showing a clear vertical and horizontal appearance of flats/apartments. Other requirements to be attached are the picture of structural plan and its calculation which clearly show the shared areas, common objects and common ground, images of the plan for general utility, installations and their equipment, for instance, network of clean water distribution, gas, and electricity.

If the developer wants to build a flat which is located on a lease area or land, the developer must attach a written agreement on the utilization of the land. After obtaining permission from the local government, the developer is obliged to request an approval from the local government concerning the fact which shows clear borders of each unit of flat/apartment, shared and joint area/land along with a description of the proportional comparison value (Nilai Perbandingan Proporsional/NPP) ${ }^{17}$. The development of flats is, therefore, carried out based on the calculation and determination of the coefficient of the building floor and the basic coefficient of the building which is adjusted to the capacity and support of the area referring to the spatial plan of the region.

Technical requirements in relation to the structure, safety and security of the building, environmental health, the comfort, and others related to the design of the building such as completeness of the infrastructure and environmental facilities. Technical requirements consist of building arrangements which are requirements of the designation of location, and intensity and architecture of buildings, the reliability of the building such as the requirements for safety, health, comfort, and convenience. Thus, the construction of flat must be planned by means of structure, component and use of construction material which fulfills the safety construction standard. In the technical aspect, flat must be completed with the interest of daily activities for dwellers, either inward or outward with provision of track, vehicle road, and parking $\operatorname{lot}^{18}$.

In addition to administrative and technical requirements, developers must also meet the ecological requirements through the assessment for environmental impact. The ecological requirements include the harmony and the balance of environmental functions. This means

\footnotetext{
certification process, facilities in the licensing process, construction credit facilities with low interest rates, tax incentives and / or provision of public utilities, facilities and utilities.

${ }^{16}$ Team writers Leks \& Co, on the book of "Real Estate Law Part 1 - Law of Land, Hosuing and Flats", published by PT Citra Aditya Bakti, Bandung, in 2017, pp. 57.

17 Erman Ramelan, on "Perlindungan Hukum Bagi Konsumen Pembeli Satuan Rumah Susun/Strata Title/Apartemen/Legal Protection for Consumer Buyers Unit Flats/Strata Title/Apartment”, published by Aswaja Pressindo, Yogyakarta, in 2015 , pp. 3. NPP is a value or number of the ratio of apartment units to the right of joint or share areas, common objects and joint land based on the size or the value of the units of apartment. The NPP is not only a description of the right of the apartment owners to land, things and shares, but also a reflection of the obligation of the owner to pay for the maintenance and repair of the joint ownership which will be imposed on him.

${ }^{18}$ Government Regulation of the Republic of Indonesia Number 4 Year 1998 concerning Flat.
} 
that density of building must reckon the eligibility of optimizing of effectiveness and efficiency of land itself, as fitted to the function by heeding harmony and safety of surrounding environment accompanied by the analysis of environmental impacts as required in the provisions of laws and regulations.

Consumer Legal Protection on Flats. Legal protection covers a wide range of subjects. They are: protected subjects, protective objects and actions which can be raised if consumers feel disadvantaged. Legal protection essentially aims to achieve the legal objectives, legal certainty, justice and benefit ${ }^{19}$. Fundamentally, legal protection relates to the provision of services to public. According to Pound (1965), law is a tool for social engineering. There are three kinds of interests which are protected, namely, public interest, social interest, and private interest. In relation to public interest, the state has a role as the guardian of the public interests ${ }^{20}$.

Protection of consumer's rights is essential where business actors and consumers according to the laizes faire paradigm are considered to have an equal position in the principle of freedom for having contract, but in reality this paradigm is not always in place. Consumers are often in a weaker or unequal position ${ }^{21}$, compared to business actors. This reality leads to the need for consumer protection, specifically through consumer protection $\operatorname{law}^{22}$. Thus, the Law on Consumer Protection is an effort for a way and process ensuring the existence of legal certainty for protecting consumers ${ }^{23}$.

Consumer legal protection is utmost important in a vibrant development of flats followed by more apartment units offered to consumers. The marketing department of flat developers offers apartment units through various strategies in the midst of strong business competition in the free market. Developers focus on a rapid process of selling the units of flat in order to have the return of investment soon ${ }^{24}$. In order to achieve that interest, developers conduct promotion by introducing or disseminating information related to flats. This phenomenon can lead to vulnerability in legal protection for consumers of the units of flat/apartment ${ }^{25}$.

Every consumer is entitled to have access to information related to the units of flat/apartment that are marketed or promoted by developers. This basic right is the right of every human being where people are entitled to obtain information as part of human right and as one of the realization of the welfare in accordance with the country's ideals and national philosophy, based on Pancasila and Article 28 F of the country's Constitution 1945, stating that everyone has rights to seek and obtain information. In relation to this right, Article 14 of the Law Number 39 Year 1999 on Human Rights stipulates that everyone is entitled to obtain necessary information to develop his/her personal and social environment. In addition, the law also affirms that everyone has the right to seek information with all types of available facilities.

\footnotetext{
${ }^{19}$ Sudjana and Elisatris Gultom, Op.cit., pp. 22.

${ }^{20}$ Roscoe Pound on the book of "Tugas Hukum, terjemahan Moh. Radja/Legal Task, translated by Moh. Radjab", published by Bharata, Jakarta, in 1965, pp. 60. Another public interest is the state's interest as a legal entity in maintaining its personality and substance.

${ }^{21}$ Henry Chambell Black, Black's Law Dictionary, West Publishing Co., St. Paul-Minnessota, 1990, pp. 1193 defines equal as 'alike, uniform, on the same plane or level with respect to efficiency, worth, value, amount or rights. Word "equal" as used in law implies not only identify but duality and used of one thing as the measure of another.

${ }_{22}$ Adrian Sutedi on the book of "Tanggung Jawab Produk dalam Hukum Perlindungan Konsumen, Product Responsibility in Consumer Protection Law", published by Ghalia Indonesia, Bogor in 2008, pp. 75.

${ }^{23}$ Sudjana and Elisatris Gultom, Opcit., pp. 33.

${ }^{24}$ Erwin Kallo, Op.cit., pp. 23.

25 Sudaryatmo, on the book of "Hukum \& Advokasi Konsumen/Legal \& Consumer Advocacy", published by Citra Aditya Bakti, Bandung, in 1999, pp. 55. In the construction of apartments, developers need to have assurance that the built apartment will be sold. Then, they conduct the marketing of units of flat/apartment on a punctual basis (pre-project selling), by having buying and selling agreement between consumers and developers. This method is taken by the developer with consideration of market certainty of obtaining cheap funds. However, from consumer protection side, this is very vulnerable. The increasingly widespread marketing is followed by the practice of selling unfinished units of flat/apartment, which are carried out with preliminary engagements or buying and selling agreement. The practice of marketing of flats is increasingly widespread, even before the accomplishment of the building; even it is when flats and apartments are still planned and still at the stage of land clearance. This is based on economic considerations: (i) for developers, it is to facilitate the acquisition of cheap funds and market certainty; (ii) for buyers or consumers is to lower the selling price of the house because the prospective buyer pays in advance.
} 
To protect consumers of the units of flat/apartment, the consumer protection law requires developers to have good intentions in conducting their business activities, including in selling their flats/apartments. They are obligated to provide true, clear and honest information regarding the condition and assurance of flats/apartments and to provide explanations of the use of flats and maintenance services. Developers are obliged to treat or serve consumers properly and honestly. The quality of apartment units built and marketed by developers must be guaranteed under the applicable quality standards. Referring to the provisions of Article 7 of Law on Consumer Protection/Undang-Undang Perlindungan Konsumen/UUPK, developers are obliged to have good intention in conducting the development of flat/apartment project and to provide the correct, clear and honest information about the condition of the flat, the period of completion and the handover of the flats physically to consumers.

In relation to promotion and marketing, the Indonesian Law on Consumer Protection can also be applied to provide legal protection for consumers of flats/apartments by arranging various restrictions against developers in order not to perform certain acts. With reference to the provisions of Article 9 paragraph (1) letter $\mathrm{j}$ and $\mathrm{k}$ at the law, the developer is prohibited to offer, promote, and advertise the units of flat or apartment improperly and to offer something that contains undefined promises. Related to this prohibition, referring to the provisions of Article 62 paragraph (1) of the Law on Consumer Protection against the developer may be imposed sanction if the developer is committed a violation with the maximum imprisonment of 5 years or a fine which is no more than Rp 2.000.000.000,00 (two billion rupiah) or \$ 142.857 USD.

Developers as the main business actors are prohibited from offering, promoting, and advertising the units of flat/apartment incorrectly using excessive words without a full description. Developer should also not offer anything containing an uncertain promise. The article 8, Paragraph (1) at letter $f$ of the Law on Consumer Protection highlights that the developer is prohibited to trade flats/apartments which are not in accordance with the promise stated in the advertisement or promotion ${ }^{26}$. Thus, developers must be responsible for units of flats/apartments as advertised ${ }^{27}$.

In offering the units of flat/apartment which are intended for selling, the developer is prohibited for offering and making false or misleading statements about the price of the units of flat/apartment, the function of flats, conditions, liabilities, guarantees, rights or compensation for the units of flat/apartment, and also for offering discounted or attractive prizes. In addition, developers in offering apartment units through orders are prohibited from failing in keeping agreements as promised and failing in keeping promises of services. This is related to the principle of the power of contract-binding.

To provide legal protection for buyers of flat/apartment units, Article 42 of the Law on Flat/UURS determines that if developers want to sell the units before the development of the flat/apartment is carried out, they must comply with several requirements, namely, the certainty of the designation of space/area indicated by the letter of city plan approved by the local government, certainty of land rights as indicated by land title certificates, certainty of the ownership status of flat/apartment, where the certainty of ownership status between Satuan Rumah Susun/SHM of apartment units and the certificate of the ownership of building or Sertifikat Kepemilikan Bangunan Gedung/SKBG of apartment units should be explained to prospective buyers ${ }^{28}$. Other requirements that must be fulfilled by the developers to be able

\footnotetext{
${ }^{26}$ Rosmawati, on the book of "Pokok-Pokok Hukum Perlindungan Konsumen/Principles of Consumer Protection Law", published by Prenada Media Group, Depok in 2018, pp. 27. Advertising on media can be divided into three types: (i) oral media; (ii) print media, such as newspapers, magazines, brochures, pamphlets, leaflets; and (iii) electronic media, such as television, radio, computer or the internet.

${ }^{27}$ Jerry J. Philips in the book of "Product Liability in a Nederland 3 rd", West Publishing Co. pp. 4. Product liability of the liability of manufacturer, processor or non-manufacturing seller for causing negative impacts to person or buyers of property or third party, caused by a product which has been sold.

${ }^{28}$ Agus Yudha Hernoko on the book of "Hukum Perjanjian Asas Proporsionalitas dalam Kontrak Komersia/Law of Principle of Proportionality in Commercial Contracts", published by Kencana Prenada Media Group, Jakarta in 2013, p. 123-124. The binding force of contract can be understood as binding on contractual obligations, that is the content of the agreement or the achievement that must be made by all parties. The binding power means that the contract is on contents or contractual achievement. Basically, a binding appointment is based on the principle of Pacta Sunt Servanda, so it needs to be given the
} 
to sell the units before the development of flats is to hold the permit for the development of flats through the IMB and collateral for the construction of flats from the guarantor institution through supporting letter from bank or non-bank.

Selling and buying of flats which have not been built or are still in the stage of development can be conducted through making a binding sale and purchase agreement/Perjanjian Pengikatan Jual Beli (PPJB). PPJB is achieved through ordering a unit to be purchased, which is then stated in the preliminary agreement or an agreement of selling and buying ${ }^{29}$. The process of buying and selling flat/apartment units before the construction finished can be done by having PPJB which written in front of notary. PPJB based on Article 42 Paragraph (1) of Law Number 1, Year 2011 is an agreement for selling and buying a house which is still in the process of building between a prospective buyer of flat/apartment and a developer who is known by official authorities.

Selling and buying the units of flat/apartment units shall be conducted based on a law as Article 1457 of the Civil Code which determines that selling and buying is an agreement among parties: one is to provide the physical of flats/apartments and the other party is to pay $^{30}$. In the concept of buying and selling, it is not only to take an object but also to give the object. As long as the transfer of the unit of flat/apartment has not occurred, this means that there is no selling and buying transaction so that the flat does not belong to the buyer. The agreement to sell and to buy indicates the presence of two parties, in which one party commits the act for selling, while the other party commits the act for buying ${ }^{31}$.

A binding sale and purchase agreement or Perjanjian Pengikatan Jual Beli/PPJB pursuant to the provision of Article 43 and Article 44 of the Law of Flat/UURS ${ }^{32}$ shall be performed after fulfilling the certainty requirements of land ownership status, ownership of license certificate, the availability of public facilities and utilities for at least $20 \%$, including the condition of the apartment units built and sold to consumers through media promotion, the location of flats, the form of apartment units, the specifications of buildings, the price of the units, infrastructure, facilities and utilities of flats and the time of transferring the units of flat/apartment. The process of buying and selling after the flats are built, there must be the selling and buying certificate/Akta Jual Beli (AJB). Developing/constructing flats/apartments is finished if there are several certificates, namely, the certificate of feasible function, letter of ownership of flats/apartments or SKBG of flat/apartment units.

Every consumer or buyer of the units of flats/apartments is entitled to legal protection, i.e. all efforts to ensure the legal certainty of protecting customers. Protection on the buyer of flats can increase the awareness, ability and independence of consumers in protecting themselves. Consumer protection creates a protection system containing elements of legal certainty and information disclosure as well as access to information. In addition, consumer protection aims to raise business awareness on the importance of consumer protection so that business transaction grows in honest and responsible attitude.

Consumer legal protection on the case of buyes of units of flat/apartment refers to Article 2 of the Law on Consumer Protection/UUPK, particularly related to the principles of consumer protection law and the legal certainty principle ${ }^{33}$. Based on that principle, both the

\footnotetext{
power of enforceability or binding contract. Legally binding and qualified contracts have binding or enforceable power equivalent to the law.

${ }^{29}$ Leks \& Co Writers Team, Analisis dan Evaluasi Peraturan Perundang-undangan tentang Perumahan Rakyat/ Real Estate Law Part 1 Land Law, Housing and Flats, Op.cit., pp. 41.

${ }^{30}$ Eman Ramelan, Op.cit., pp. 28.

${ }^{31} \mathrm{Ibid}$., pp. 29. There are two concepts of transition rights as regulated in the Law of Flat/UURS, namely: (i) buying and selling committed by developers to the public or users; and (ii) buying and selling which is done by the owner to other buyers.

${ }^{32}$ The provisions on the same requirements have also been regulated in Article 42 of Law Number 1 Year 2011, on Housing and Settlement Area. In doing marketing, developers use mass media. Newspaper media is still the most favorite for promotion for developers. Buyers of the units of apartment have rights as consumers, such as: the right for information; the right for security and comfort; and the right for indemnification.

${ }^{33}$ Soerjono Soekanto, on the book of "Pengantar Penelitian Hukum/Introduction to Legal Research", published by UI Press, Jakarta in 2010, pp. 45. Paton argues that the principle of law is an essential element of the rule of law. The principle of law is at the heart of the rule of law, for it is the broadest foundation for a rule of law. This means that the rule of law can ultimately be restored to these principles. This principle of law is worth mentioning as the reason for the existence of the rule of law, or it is the legitimate ratio of the rule of law. The principle of law is not exhausted by the existence of a rule of law, but it will still exist and will give extend of further rules. Therefore, Paton calls it as a means by which the law is alive, growing and developing and it also shows that the law is not merely a collection of rules.
} 
developers and the interest of buyers must obey the law and obtain justice in the implementation of consumer protection, and the state guarantees on the legal certainty. With the principle of legal certainty, developers perform their duties in honest attitude and they have the intention to implement it wholeheartedly.

With regard to the marketing of units of flat/apartment followed by bundling agreement of selling and buying between developers and buyers, the Law provides protection for the buyers in the form of Decree of the State Minister for Public Housing Number 11/KPTS/1994 on the Guidance on Assembly of Selling and Buying of the units of flat/apartment. Thus, in the process of selling and buying agreement, every developer of the flat/apartment must obey the Ministerial Decree.

Selling and buying the units of flat/apartment should be conducted in the presence of notary for writing land certificate/Pejabat Pembuat Akta Tanah/PPAT after all conditions of transaction have been fulfilled by all parties. The transaction with binding agreement is required as a guarantee for both parties; this agreement is seen from the point of selling and buying agreement that buyers will pay the unit in accordance with the time agreed in the agreement. For the buyer, the binding agreement provides assurance where the unit of flat/apartment will not be sold to another party by the developer and the unit will be handed in to the buyer within the agreed time. The selling and buying binding agreement is an agreement in which the seller binds to sell the unit to the buyer and the buyer binds himself/herself to pay the price of the unit bought. Although there exist a selling and buying agreement, as long as the unit of flat/apartment has not been given to the buyer, the property right on the item is still on the side of seller.

To ensure the implementation of a binding sale and purchase agreement or Perjanjian Pengikatan Jual Beli/PPJB in accordance with the prevailing rules, the Government exercises control and supervision officially at all government levels: Ministers at the national level; Governors at the provincial level; and Regents/Mayors at the district/city level. Control is needed to ensure the development of the flat/apartment, including control to marketing processes. Control or supervision is practiced through several stages, namely: monitoring, evaluation, and corrective actions in accordance with the provisions of legislation.

A binding sale and purchase agreement or Perjanjian Pengikatan Jual Beli/PPJB includes an object to be traded, management and maintenance of shared area, common objects, and common lands which are the duty of all residents and the developer. Regarding the object to be traded, the flats/apartments must have the necessary permits, such as location permit, proof of land ownership and payment, and building permit. Regarding the management and maintenance of shared parts, common objects, and common ground which is the responsibility of all residents, prospective buyers must be willing to become a member of PPRS.

Regarding the liability of the developer, prior to conducting the initial marketing, the developer must report all related marketing to Regents/Mayors with a copy to the Indonesian Minister of Public Housing. The report shall be accompanied by several documents. They are: (1) a copy of the permit letter of principle; (2) a copy of the location permit; (3) proof of land acquisition and procurement; (4) a copy of the building permit letter; (5) the picture of design of flats/apartments which has been approved by the local government. If within 30 days since the date indicated on the receipt of the report has not received any answer from the relevant agency, such a bid may be proceed. Developers are obliged to provide all documents related to housing construction, such as (a) the land title certificate, (b) the site plan, (c) draft of architecture plan containing the site plan and cross-section with its details which show clear limit in vertical or horizontal direction of flat, (d) the picture of the structure plan and its calculations, (e) draft of structure plan which shows clearly mutual-part, mutualobject, and mutual land, (f) draft of the network, installation, equipment plan and accessories.

Another obligation for developers to undertake is for completing the construction of building in accordance with the agreed standard, preparing the agreement of selling and buying the units of flat/apartment/ certificate of selling and buying/Akta Jual Beli (AJB) which is signed by both parties in the presence of the Notary/ Official for Writing Land Certificate/Pejabat Pembuat Akta Tanah/PPAT on the stipulated date; and/or Notary/PPAT 
will arrange the acquisition of the certificate of the units of flat/apartment on behalf of buyers. Developers are also obligated to deliver the units of flat/apartment, including public and social facilities perfectly on the specified date.

If developers have not been able to complete the units of flat/apartment at the specified/agreed time, they shall be granted a period of 120 (one hundred and twenty) calendar days to complete the construction, as from the date of the plan to hand in the units. If they still cannot fulfill the promise so the Agreement on Binding for Selling and Buying/Perjanjian Pengikatan Jual Beli/PPJB will be cancelled legally. The cancellation of PPJB does not need to be proven or sought by a court decision or an arbitration body. Developers are obliged to refund the payment received from buyers with additional cost for penalty and monthly interest, according to the prevailing of bank interest rate. Consumer legal protection of the units of flat/apartement can be done by tightening and enforcing rules of making PPJB. This can strengthen the position of consumers as parties who are often in a weak position. Thus, the PPJB's role is to make a balance interests between developers and consumers. This relates to the idea of fairness through impartiality of business contract ${ }^{34}$.

To protect consumers of the units of flat/apartment, there are also legal instruments which can be applied to developers, namely Government Regulation No. 88 of Year 2014 on the Development of Housing and Settlement Areas ${ }^{35}$. Based on the regulation, the Government, Ministers, Governors, and Regents/Mayors in accordance to their authorities can be advisors for developers and also to public as the stakeholders of the development of flats or apartments ${ }^{36}$. Thus, assistance and coaching are conducted through three different levels: National level with Ministers; Provincial level with Governors; and at District/City level with Regents or Mayors.

Assistance and coaching can be conducted on several aspects such as control and supervision. Control can focus on a house, housing, settlement, and residential area. Control is carried out on licensing, monitoring, and arranging on housing and settlement area at local government of regency/city where in the Capital city of Jakarta, it should be at the government of province. In addition, supervision is carried out through monitoring, evaluation and correction activities in the implementation of housing and settlement areas. Monitoring activity is an activity to conduct observation and recording of housing and residential area. Evaluation activities are activities to assess and measure the results of the implementation of housing and residential areas. Correction activities are activities to provide recommendations on the improvements from the results of the evaluation on housing and residential areas.

Each developer should also understand laws and regulations on flats and consumer protection; therefore, it is necessary to socialize the legislation by the Minister to the Governors and/or Regents/Mayors. Socialization is conducted by disseminating information on laws and regulations including norms, standards, procedures and criteria not only to local governments but also to developers and consumers as stakeholders of flats/apartments. The reason is that society as consumers are in need of socialization of the legislation related to the flat. Thus, in generally consumers require mentoring and empowerment as well as need for information and communication services.

\footnotetext{
${ }^{34}$ Brinkmann, Johannes, on the journal "Putting Ethics on the Agenda for Real Estate Agents". Journal of Business Ethics, 88:65 - 82. 2009

\begin{abstract}
${ }^{35}$ Government Regulation Number 88 Year 2014 on the Development of Housing and Settlement is intended as a regulation for implementing the provisions of Article 11 of Law Number 1 Year 2011 on Housing and Settlement Area and Article 12 of Law Number 20 Year 2011 on Flats. Article 12 of Law Number 20 Year 2011 on Flats mandates for further regulation with the government regulation on the state responsibility for the administration of flats whose development is carried out by the government. On the other hand, Article 11 of Law Number 1 Year 2011 concerning Housing and Settlement Area shall instruct further regulation with the government regulation on the State responsibility for the implementation of housing and settlement areas whose guidance is implemented by the government.
\end{abstract}

${ }^{36}$ Under the provisions of Article 2 Paragraph (2) Letter a, the stakeholders are, among others, private, financial institutions, developers, contractors, academicians of higher education, and society in general. 


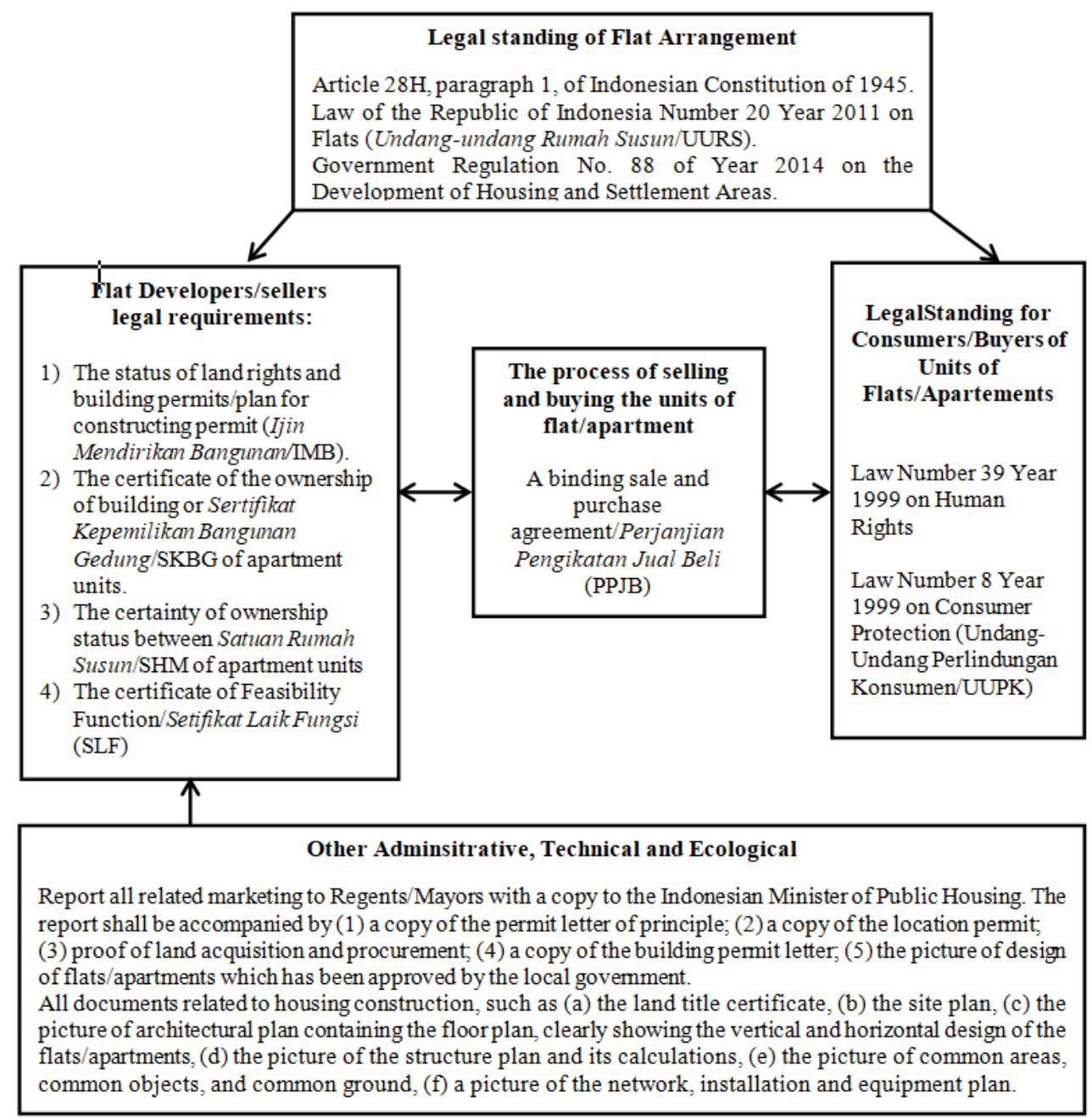

Diagram 1 - Mapping of Consumer Legal Protection in relation to the Law on Flat Management

\begin{tabular}{|c|c|}
\hline $\begin{array}{c}\text { Aspects which need to be considered: } \\
\text { Regulate sanctions for developers who offer, promote, } \\
\text { advertise apartment units incorrectly either in the form of } \\
\text { criminal sanctions for imprisonment or criminal penalties. }\end{array}$ & $\begin{array}{c}\text { Law of the Republic of Indonesia } \\
\text { Number 20, Year 2011 on Flats } \\
\text { (Undang-undang Rumah } \\
\text { Susun/UURS) }\end{array}$ \\
\hline
\end{tabular}

Diagram 2 - Framework for Revision of the Indonesian Law on Flat in the aspect of Consumer Legal Protection

Moreover, each developer should have a detailed socialization or explanation to the buyer if the developer wants to sell the units, for example there is a rule that property development of flats/apartment is obliged to manage flats in the transition period, not later than one year since the first times of the units of flat/apartment hand them to buyers. Within one year, the developer is obliged to establish the association of owners and tenants of flats/Perhimpunan Pemilik dan Penghuni Satuan Rumah Susun/P3SRS, where the residents have the authority to choose their own P3SRS management. Buyers should also get a detailed explanation of the area management fee/luran Pemeliharaan Lingkungan (IPL) with all its components, such as parking, water and electricity. The obligations of developers need to be monitored by the government. So for ensuring the compliance of developers with all rules, it is not excessive for the government to exercise its authority to control, supervise and guide which is regulated in Law Number 20 of 2011. The law states that by complying with all rights and obligations to be fulfilled by developers, these are connected with the granting of a license to build/ IMB and certificate of Feasibility Function/Setifikat Laik Fungsi (SLF) as referred to in Article 39 paragraph (3) of Law Number 20 of the Year 2011. The provisions of 
the law actually have opened the authority i.e. the government to play a role in providing consumer protection through licensing.

The authority of both the Central Government and the Local Government explained above should be a form of consumer law protection by lawmakers in very strategic and solid, protection which start from preventive actions in overcoming the problems that arise in order to guarantee the implementation of housing and residential areas including flats when consumers are dealing with developers. Without any government assistance to buyers, then any case of injustice of consumers as the flat/apartment's buyers will be difficult to overcome.

\section{CONCLUSION}

It has been explained that flat/apartment developers can conduct marketing and selling the units of flat/apartment even though the development has not been implemented. However, the practice cannot be proceeding if developers failed to meet all the requirements. The fact is that developers sell units of flat/apartment before fulfilling all legal requirements, although developers and consumers engage in the binding agreements of selling and buying flats/apartments. This paper argues that in this situation consumers are in a weak position and incur losses. Therefore, each developer has to socialize and give a detailed explanation to consumers in the process of selling and buying the units of flat/apartment. In terms of consumers, since they are in a disadvantage position in the marketing process of the units of flat/apartment in the case of the buildings have not been finished or there is no completion of development, they should pay attention to the legality of the development of the units marketed.

Consumer protection law in the context of flat is practiced in the aspect of promotional and marketing advert of the units of flat/apartment. But, this paper argues that in the context of Indonesia, there are no sanctions for developers who violate the law. This paper suggests on the ideas of strengthening and enforcing the law on flat. The first is that developers are obliged to comply with the guideline of selling and buying of the units of flat/apartment under the Decree of the Minister of Public Housing. The second is that developers, who offer, promote, advertise the units of flat/apartment incorrectly may be subject to imprisonment or fine penalties. The third is that developers who make the agreement of binding for selling and buying/PPJB which are not in accordance with what is marketed and agreed with buyers; or has not fulfilled the requirements of the land ownership status, the ownership of the permit for develop flats/apartment/IMB, the availability of public utilities and facilities with at least twenty percent; and other aspect which are agreed in the agreement may be subject to imprisonment or a fine.

Therefore, with regard to the legal instruments governing marketing prior to development of flat/apartment, there is the need of a revision of Law Number 20 of the Year 2011 and the Law Number 1 Year 2011 to regulate sanctions for developers who offer, promote, advertise apartment units incorrectly either in the form of criminal sanctions for imprisonment or criminal penalties. Prevention in the form of preventive measures can also be carried out by the government in carrying out supervisory and coaching functions through the extension of licensing requirements by requiring all aspects to ensure that consumers are properly protected according to propriety and fairness. The sanctions for developers are a rule in the legal instrument which can ensure that they must have good faith by fulfilling all requirements for selling the units flat/apartment preceded by the Agreement on Binding for Selling and Buying/Perjanjian Pengikatan Jual Beli/PPJB. Thus, this paper suggest for further research and advocacy on the revision of Law Number 20 of the Year 2011 and the Law Number 1 Year 2011 for Flat, in more protecting consumers in the process of selling and buying flats/apartments.

\section{REFERENCES}

1. Black, Henry Chambell, Black's Law Dictionary, West Publishing Co., St. PaulMinnessota, 1990. 
2. Brinkmann, J. Putting Ethics on the Agenda for Real Estate Agents. Journal of Business Ethics, 88:65 - 82, 2009.

3. Hernoko, Agus Yudha, Hukum Perjanjian Asas Proporsionalitas dalam Kontrak Komersial, Jakarta: Kencana Prenada Media Group, 2013.

4. Hutagalung, Arie S, Tebaran Pemikiran Seputar Masalah Hukum Tanah, (Jakarta: Lembaga Pemberdayaan Hukum Indonesia, 2005.

5. Hutagalung, Arie S, Kondominium dan Permasalahannya, Edisi Revisi, Jakarta: Badan Penerbit Fakultas Hukum Universitas Indonesia, 2007.

6. Kallo, Erwin, Panduan Hukum untuk Pemilik/Penghuni Rumah Susun (Kondominium, Apartemen dan Rusunami), Jakarta: Minerva Athena Pressindo, 2009.

7. Leks, Eddy Marek (Ketua Kelompok Kerja), dalam "Analisis dan Evaluasi Peraturan Perundang-undangan tentang Perumahan Rakyat," Pusat Perencanaan Pembangunan Hukum Nasional Badan Pembinaan Hukum Nasional Kementerian Hukum dan Hak Asasi Manusia, 2013.

8. Leks, Eddy M, Panduan Praktis Hukum Properti-Memahami Problematika Hukum Pertanahan, Perumahan, serta Pengembangannya, Jakarta: PT Gramedia Pustaka Utama, 2016.

9. Leks \& Co, Hukum Real Estat Bagian 1 Hukum Pertanahan, Perumahan dan Rumah Susun, Bandung: PT Citra Aditya Bakti, 2017.

10. Manzo, C. Lynne. On uncertain ground: being at home in the context of public housing redevelopment, International Journal of Housing Policy, 14:4, 389-410, 2014.

11. Philips, Jerry J. Product Liability in a Nederland $3 \mathrm{rd}$, West Publishing Co.

12. Pound, Roscoe, Tugas Hukum, terjemahan Moh. Radjab, Jakarta: Bharata, 1965.

13. Ramelan, Erman, Perlindungan Hukum Bagi Konsumen Pembeli Satuan Rumah Susun/Strata Title/Apartemen, Yogyakarta: Aswaja Pressiondo, 2015.

14. Rolnik, R. Place, inhabitance and citizenship: the right to housing and the right to the city in the contemporary urban world, Int. Journal of Housing Policy, 14:3, 293-300, 2014.

15. Rosmawati, Pokok-Pokok Hukum Perlindungan Konsumen, Depok, 2018.

16. Soekanto, Soerjono, Pengantar Penelitian Hukum, Jakarta: UI Press, 2010.

17. Subekti, Hukum Perikatan, Jakarta: Intermasa, 1983.

18. Sudaryatmo, Hukum \& Advokasi Konsumen, Bandung: Citra Aditya Bakti, 1999.

19. Suhadi, Aspek Hukum dan Sosial Rumah Susun, Semarang: Badan Penerbit Fakultas Hukum Universitas Negeri Semarang, 2017.

20. Sutedi, Adrian, Hukum Rumah Susun \& Apartemen, Jakarta: Sinar Grafika, 2010.

21. Sutedi, Tanggung Jawab Produk dalam Hukum Perlindungan Konsumen, Bogor, 2008.

22. Sudjana, Rahasia Dagang dalam Perspektif Pelindungan Konsumen, Bandung, 2016.

23. Syarifuddin, Muhammad, (Hukum Kontrak (Memahami Kontrak dalam Perspektif Filsafat, Teori, Dogmatik, dan Praktek Hukum), Jakarta: Mandar maju, 2012.

24. Black's Law Dictionary Free Online Legal Dictionary 2nd Ed. Pada https://thelawdictionary.org/product. Diakses 29 Maret 2018.

25. Hendra Kusuma, Detik Finance, "Deddy Mizwar Minta Proyek Meikarta Disetop," pada https://finance.detik.com, diakses 1Maret 2018.

26. Nola, "Permasalahan Hukum dalam Praktik Pre-Project Selling Apartemen" pada Majalah Hukum Singkat, Pusat Penelitian Badan Keahlian DPR RI ISSN Vol. IX, No. 18/II/Puslit/September/2017, pada www.puslit.dpr.go.id., diakses 27 Maret 2018.

27. Pusat Komunikasi Publik Kementerian Pekerjaan Umum dan Perumahan Rakyat Republik Indonesia, "Backlog Perumahan Mencapai 5,8 Juta Unit".

28. Suhendra, Zulfi - Detik Finance, "Ini Alasan Deddy Mizwar Hanya Beri Rekomendasi Meikarta $84 \mathrm{Ha}$," pada https://finance.detik.com, diakses 16 Februari 2018.

29. Subekti, R dan R. Tjitrisudibyo, "Kitab Undang-undang Hukum Perdata", Terjemahan dari Burgerlijk Wetdoek, Cetakan ke 34, Jakarta. PT. Pradnya 2004

30. UndangUndang Nomor 1 Tahun 2011 tentang Perumahan dan Kawasan Permukiman.

31. Undang-Undang Nomor 20 Tahun 2011 tentang Rumah Susun.

32. Peraturan Pemerintah Nomor 88 Tahun 2014 tentang Pembinaan Penyelenggaraan Perumahan dan Kawasan Permukiman. 